\title{
THE EFFECT OF PERFORMANCE MEASUREMENT SYSTEM AND REMUNERATION TO EMPLOYEE PERFORMANCE WITH ORGANIZATIONAL CULTURE AS A MODERATING VARIABLE Dewi Noor Fatikhah Rokhimakhumullah ${ }^{1}$
}

\author{
University of Brawiyaja, Malang, Indonesia ${ }^{1}$
}

\begin{abstract}
This study aims to examine the effect of performance measurement system and remuneration on employee performance with organizational culture as moderating variable. This research uses survey research design with Partial Least Square (PLS) data analysis. Respondents in this study are 66 employees who have structural positions in KPP Madya Malang and KPP Pratama Batu. The results showed that the performance measurement system can improve employee performance. The results of this study demonstrated that organizational culture as a moderating variable was able to strengthen the relationship of performance measurement system and remuneration to employee performance. In addition, the results of the study was unable to prove that remuneration can improve the employees' performance, because the remuneration given by the directorate general of taxes is not accompanied by a good performance appraisal.
\end{abstract}

Keywords: Performance measurement system; remuneration; organizational culture; employee performance

\section{Introduction}

The Directorate General of Tax (DGT) is one of the most vital government organizations. The DGT has the primary duty of collecting the central tax. In order to execute control and evaluation on the DGT and subordinate working units in carrying out its duties, it is necessary to conduct a performance measurement.

Performance measurement system that has been applied by the DGT in the form of Main Performance Indicators (IKU) of employees (KMK No. 467 /KMK.01/2014 on Performance Management in the Ministry of Finance). In addition to implementing an effective performance measurement system, remuneration in government is also an integral part of bureaucratic reform policy. This policy is expected to create a breakthrough on the phenomenon that shows the bad image of public sector employees today. In accordance with Presidential Regulation no. 136 of 2014 on Employee Performance Allowances in the Ministry of Finance and Presidential Regulation No. 37 of 2015 on Employee Performance Allowances in the Directorate General of Taxes Environment.

In 2015, the Regional Office of DJP East Java III has many achievements. The performance of Regional Offices of East Java DJP III got the first rank of national, the performance of KPP Madya Malang is the best national KPP Madya, and the performance of KPP Pratama Batu is the best National Pratama KPP for 2015 (Malang Post, 01 January 2016). However in fact, the remuneration that will be received by tax officials of DJP Regional Office III East Java for the year 2016 will decrease, because the decreasing national income, so that will affect the performance.

The results of previous studies showed that the relationship between performance measurement system and employee performance gave inconsistent results. The results of Hoque and James, 2000; Davis and Albright, 2004; Braam and Nijssen, 2004; Rahman, Nasir, and Handayani, 2007; Mintje, 2013; found that there was a positive and significant influence between performance measurement systems and employee performance. While the results of Kald and Nilsson, 2000; Speckbacher, Bischof and Pfeiffer, 2003; Hudson, Smart and Bourne, 2001; Hall, 2008; Jusuf, 2013; Simamora, 2014 shows an insignificant relationship.

\footnotetext{
${ }^{1}$ dewinoorfatikhah@gmail.com
} 
The differences in the results of the research encouraged the researchers to examine again by using contingency factors. The contingent variable to be used in this research is organizational culture. The research results of Ng'ang'a and Nyongesa (2012), Santoso, dkk (2013), Juliningrum (2013), Awadh and Saad (2013), Rusman (2015) found that organizational culture has a positive effect on employee performance. Organizational culture can be used as a moderating variable because it can strengthen the relationship of performance measurement systems and remuneration to employee performance (Hoftsede et al., 1990; Goddard, 1997; O'Connor, 1995; Subramaniam and Ashkanasy, 2001; Sardjito, et al., 2007) . The dissimilarity of this research with previous research is by testing the influence of performance measurement system and remuneration on employee performance using contingency theory, with the addition of organizational culture variable as moderating variable. The sample used in this research is employees of Malang Tax Service Office and Tax Office Pratama Batu, because both KPP has received the first national ranking for achievement of performance.

\section{Literature Review}

Performance measurement system is a very important thing to be done by the company in order to improve organizational performance. On the way to improve the performance of employees, the organization also needs to pay attention to the rewards provided to employees for the resulting performance, namely by providing remuneration.

Based on the theory of contingencies there is no universal control system that is always appropriate to apply to the whole organization in every circumstance (Fisher, 1998). Organizational culture can be used as a moderating variable for it can strengthen the relationship of performance measurement systems and remuneration to employee performance (Hoftsede et al., 1990; Goddard, 1997; O'Connor, 1995; Subramaniam and Ashkanasy, 2001; Sardjito, et al., 2007).

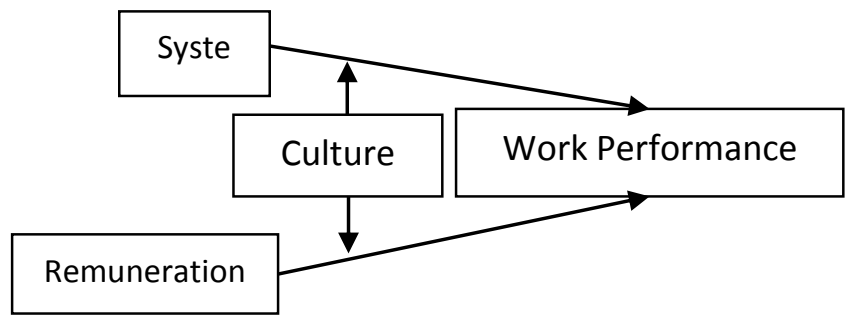

Figure 1. Conceptual Research Framework

Based on conceptual framework of research, hence can be proposed research hypothesis as follows: H1: Performance Measurement System Has Positive Influence on Employee Performance

H2: Remuneration has a positive effect on employee performance

H3: Positive Impact of Performance Measurement System on Employee Performance is strengthened by Organizational Culture

H4: Positive Impact of Remuneration on Employee Performance is reinforced by Organizational Culture

\section{Methodology}

The population in this study are all employees who have structural positions in KPP Madya Malang and KPP Pratama Batu, which amounted to 189 people. The sample used is 66 people. The data used by the researchers is primary data obtained directly from the respondents. Methods of data collection is done by distributing a number of statement items with a closed format in the form of questionnaires to the respondent.

Moreover, the data analysis employed in this research was Partial Least Square (PLS) with the help of SmartPLS 2.0 application. The analysis model using PLS which uses several steps, namely designing the structural model (inner model), designing the measurement model (outer model), and constructing the path diagram.

\section{Result and Discussion}

Convergent validity can be seen in table 2 which shows the AVE and communality values of all constructs over 0,50. Thus, the value of AVE and communality has met the rule of thumb test of convergent validity (Chin, 1995 in Hartono and Abdillah, 2015: 195). This indicates that the data has been valid for 
subsequent testing.

Discriminant validity test results based on the value of cross loading (attachment) is the value of cross loading on each construct indicator has a higher value or accumulate on a predefined construct. This proves that each construct can predict the indicators on their block better than other block indicators. Based on table 2 it can be seen that the reliability of all constructs has composite reliability value $>0.60$ and cronbach's alpha is more than 0.70 . Hence, it can be concluded that the indicator of each construct has been reliable. The value of R2 employee performance as shown in table 2 is 0.866679 . This explains that employee performance constructs can be explained $86 \%$ through the construction of performance measurement systems, remuneration, and organizational culture; while $14 \%$ is explained through constructs outside the model.

In addition to viewing the value of R2, the structural model measured by the PLS is expected to have predictive relevance $(\mathrm{Q} 2)$. Predictive relevance $(\mathrm{Q} 2)$ measures how well the observed values generated by the model and its parameter estimates (Ghozali, 2011: 26). If the value of Q2 is greater than zero, indicating the inner model has predictive relevance. The value of Q2 is calculated by the formula: $\mathrm{Q} 2=1-(1-\mathrm{R} 2)$

$\mathrm{Q} 2=1-(1-0.7511)$

$\mathrm{Q} 2=0.7511$

The calculation results show the value of Q2 for the inner model of 0.7511 which means that this research model has a large predictive relevance, because the value is greater than zero so it is suitable for hypothesis testing.

The result of testing of structural model is evaluated by using significance test through bootsraping process on PLS by using coefficient of path, while moderation effect of significance test is seen in Total Effect table, because there is also a testing in moderation effect which examine the interaction relationship between independent variable and moderation variable to dependent variable (indirect effect). The drawing of the research path diagram is summarized as follows:

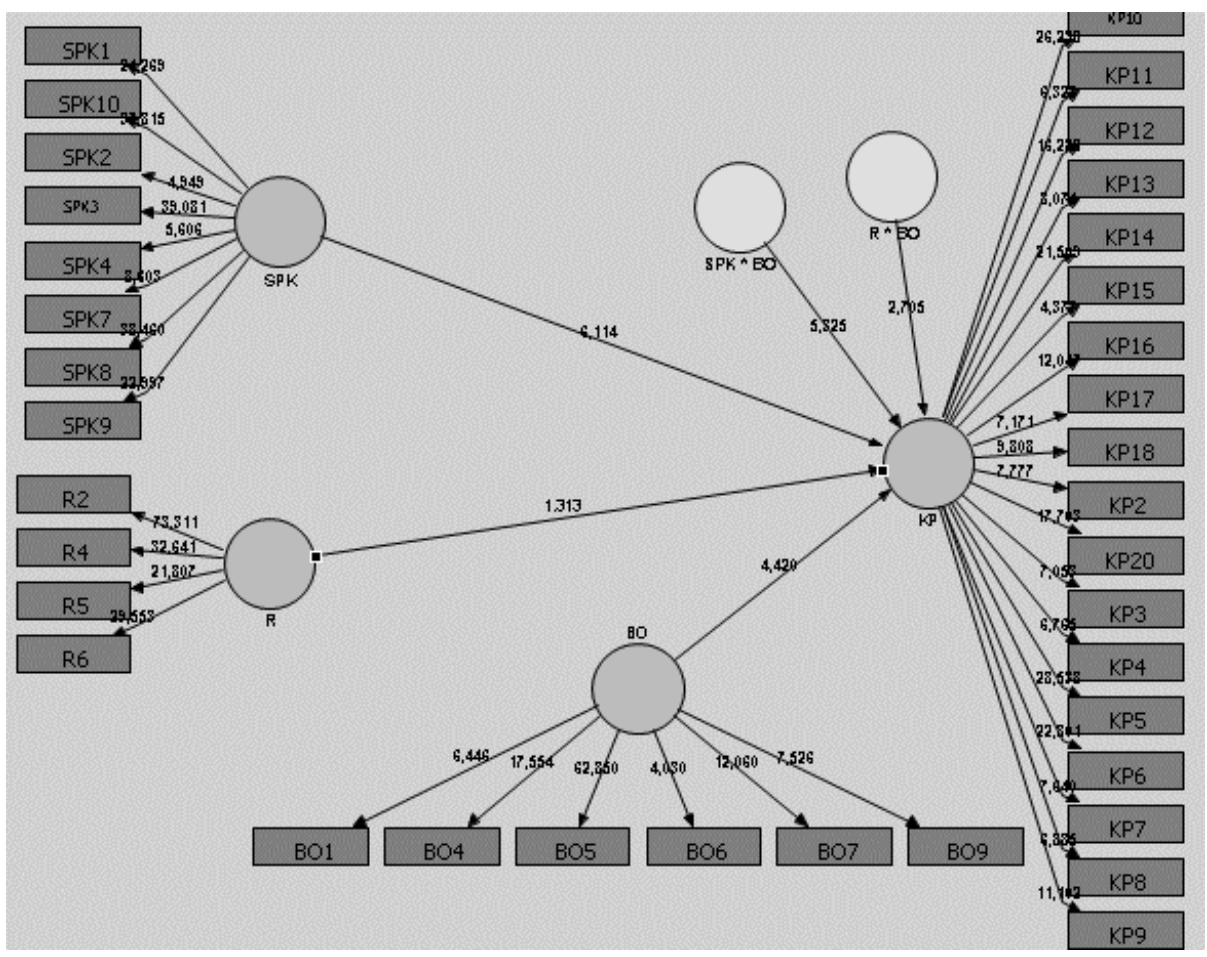

Figure 2. Research path diagram 
The results of hypothesis testing presented in table 1 as follows:

Table 1. Hypothesis testing

\begin{tabular}{|c|c|c|c|}
\hline & $\begin{array}{l}\text { Original Sample } \\
\text { (O) }\end{array}$ & T Statistics (|O/STERR $\mid)$ & Note \\
\hline$\left(\mathrm{H}_{1}\right) \mathrm{SPK}$-> KP & 3,231 & 6,114 & Accepted \\
\hline$\left(\mathrm{H}_{2}\right) \mathbf{R}$-> KP & $-0,067$ & 1,313 & Rejected \\
\hline $\begin{array}{l}\left(\mathbf{H}_{3}\right) \mathbf{S P K} * \mathbf{B O}-> \\
\mathbf{K P}\end{array}$ & 2,411 & 5,325 & Accepted \\
\hline$\left(\mathbf{H}_{4}\right) \mathbf{R} * \mathbf{B O}->\mathbf{K P}$ & 1,176 & 2,705 & Accepted \\
\hline
\end{tabular}

\section{Conclusions, suggestions and limitations}

From Table 1 above, the researcher summarized:

1. Hypothesis testing shows results that support the initial hypothesis. Thus it can be said that these findings support the first hypothesis. The results of this study are consistent with the results of previous research, namely the research conducted by Rahman, Nasir, and Handayani (2007), Tupamahu (2009), and Tarigan (2011) stating that the performance measurement system has a positive and significant impact on performance. Performance measurement systems can assist the decision-making process and help evaluate past decisions (Malina and Selto, 2001) to improve performance based on predetermined standards in order to succeed the implementing of corporate strategy. The performance measurement system implemented by the Directorate General of Taxes (DGT) in the form of Main Performance Indicator (IKU) can be a benchmark for achieving strategic goals that can be achieved by each employee. With a clear and standardized performance measurement system, employee performance can be evaluated directly, the higher IKU points gained, showing better employee performance.

2. Hypothesis testing shows results contrary to the initial hypothesis. The results showed that the remuneration had a negative and insignificant effect on employee performance. Thus it can be said that these findings do not support the second hypothesis. These findings are inconsistent with previous research, ie Widyastuti (2010), Sancoko (2010), Santoso (2013), Wilfred, Elijah, and Muturi (2014) studies; and Fitria, et al (2014) who found a positive and significant influence between remuneration and employee performance. However, this study reinforces the research of Mensah and Dogde (2011) who found that remuneration does not have an effect on employee performance improvement. The realization of national tax revenue in 2015 is only $81.5 \%$ of the revenue target, so that based on Presidential Decree No.37 of 2015 on Employee Performance Allowance in the Directorate General of Tax Environment, remuneration (paid allowances) paid to tax employees only $80 \%$. This condition will result in the injustice of remuneration received by the employee of the tax. Employees who work in areas with high tax revenue targets with large taxpayers, such as big cities, require intensive performance, whereas employees who are in areas with relatively small revenue targets and taxpayers which is not too much, then the required performance is also not very intensive. So it will be very influential on employee performance.

3. The third hypothesis states that the positive effect of performance measurement system on employee performance is reinforced by organizational culture. The results showed that organizational culture is able to moderate the relationship between performance measurement system on employee performance. The results of this study are in line with the results of the research of Muparrih, dkk (2009), Juliningrum (2013), Awadh and Alyahya (2013), Ng'ang'a and Nyongesa (2012). The results of this study do not support Schein's (1996) research that performance appraisal systems can help find and formulate important aspects of culture with behavioral specifications and competencies that employees contribute to the success of organization, unit, group, or position. The results of this study support contingency theory in the context of performance measurement system relationship with employee performance. Organizational culture can moderate the influence of performance measurement systems on employee performance. Strong culture can be found in detailed policies, organizational structures, procedures and regulations. A clear performance measurement system accompanied by the application of organizational culture of conducive behavior of employee, can improve employee performance, because employees always encouraged to maximize performance in a respectable environment. 
4. The results show that the culture of the organization can strengthen the relationship between remuneration and employee performance. The results of this study are consistent with the research of Kotler (1994) and Rowley and Jackson (2010) stating that the provision of remuneration can improve employee performance. This finding also supports contingency theory in the context of remuneration relationships with employee performance. Organizational culture can strengthen the relationship of remuneration with employee performance. With the remuneration, which is reinforced with a good organizational culture, it will improve the performance of employees, because employees will be accustomed to act to follow the existing culture within an organization.The use of modified likert scale (Arikunto, 2010) causes the respondents have less varied option of alternative answers, which may affect the results of research. Further research is expected to use Likert measurement scale with more varied alternative answers.

This study cannot prove that remuneration can improve employee performance. This is because the remuneration given by the DGT is not based on local achievement, but based on the achievement of national tax revenue target. Therefore, the suggestion for the government is to review the existing regulations regarding the acceptance of remuneration within the DGT.

\section{References}

Anthony, R and Govindarajan, V. 1998. Management Control System, Ninth Edition. The Mc Grow-Hill. Bernardin, H, J., dan Russel, J, E, A. (2003). Human Resource Management (An Experimental Approach International Edition). Mc. Graw-Hill Inc Singapore.

Boedianto, S. 2012. Pengaruh Pemberian Remunerasi terhadap Kinerja Pegawai Lembaga Pemasyarakatan Kelas IIA Anak Blitar. Jurnal Ilmu Manajemen, REVITALISASI, vol. 1, no.3.

Braam, G dan Nijjsen, E. 2004. Performance Effects of Using the Balanced Scorecard: A Note on The Dutch Experience. Long Range Planning 37, pp.335-349.

Davis, S dan Albright, T. 2004. An Investigation of The Effect of Balanced Scorecard Implementation on Financial Performance. Management Accounting Research 15, pp. 135-153.

Deluca, M, J. 1993. Handbook of Compensation Management. New Jersey, US: Prentice-Hall.

Fitria, R., Idris, A., dan Kusuma, A. R. 2014. Pengaruh Remunerasi, Motivasi dan Kepuasan Kerja Terhadap Kinerja Pegawai di Kantor Pengadilan Tinggi Agama Samarinda. eJournal Administrative Reform 2, pp. 1691-1704.

Ghozali, I. 2008. Structural Equation Modelling Metode Alternatif dengan Partial Least Square. UNDIP. Semarang.

Govindarajan, V. 1986. Impact of Participation in the Budgetary Process on Managerial Attitudes and Performance: Universalistic and Contigency Perspective. Decision Sciences, pp. 496-516.

Govindarajan, V. 1988. A Contingency Approach to Strategy Implementation at the Business - Unit Level : Integrating Administrative Mechanisms with Strategy. Academy of Management Journal 31, pp. $828-853$.

Hall, M., 2008. The Effect of Comprehensive Performance Measurement Systems on Role Clarity, Psychological Empowerment and Managerial Performance. Accounting, Organizations and Society 33, pp. 141-163.

Hartono, J. dan Abdillah, W. 2015. Partial Least Square (PLS) Alternatif Structural Equation Modeling (SEM) dalam Penelitian Bisnis. Yogyakarta : Andi.

Hatch, J.M. 1997. Organizational Theory: Modern, Symbolic, and Postmodern Perspectives. Oxford University Press.

Henry, J.F., 2006. Organizational Culture and Performance Measurement Systems. Accounting, Organizations and Society 31, pp. 77-103.

Hofstede, G., Neuijen, B., Ohayv, D., Sanders, G. 1990. Measuring Organizational Cultures:A Qualitative and Quantitative Study across Twenty Cases. Administrative Science Quarterly 35, pp. 286-316.

Hoque, Z., dan James, W. 2000. Lingking Balanced Scorecard Measures to Size and Market Factors: Impact on Organizational Performance. Journal of Management Accounting Research 12, pp. 1-15.

Hoque, Z., Mia, L., dan Alam, M. 2001. Market Competition, Computer-Aided Manufacturing and Use of Multiple Performance Measures: An Empirical Study. British Accounting Review 33, pp. 23-45.

Ittner, C.D., Larcker, D.F. 2001. Assessing Empirical Research in Management Accounting: A Value Based Perspective. Journal of Accounting and Economics 32, pp. 349-410. 
Ittner, C.D., Larcker, D.F., dan Randall, T. 2003. Performance Implications of Strategic Performance Measurement in Financial Services Firms. Accounting, Organizations and Society 28, pp. 715741 .

Jensen, M.C., dan Meckling,W.H. 1976. Theory of the Firm: Managerial Behavior, Agency Costs and Ownership Structure. Journal of Financial Economics 3, pp. 305-360.

Juliningrum, E., Sudiro, A. 2013. Pengaruh Kompensasi, Budaya Organisasi, Terhadap Motivasi Kerja dan Kinerja Pegawai. Jurnal Aplikasi Manajemen, vol.11, no.4.

Jusoh, R., Ibrahim, D.N., Zainuddin, Y. 2008. The Performance Consequence of Multiple Performance Measures Usage: Evidence from the Malaysian Manufacturers. International Journal of Productivity and Performance Management 57, pp. 119-136.

Jusuf, R.S. 2013. Analisis Pengaruh TQM, Sistem Pengukuran Kinerja dan Reward terhadap Kinerja Manajerial. Jurnal EMBA vol.1, no.3, pp. 634-644.

Kald, M dan Nilsson, F. 2000. Performance Measurement at Nordic Companies. European Management Journal 18, pp. 113-127.

Kawedar, W. 2015. Pengaruh Penganggaran Partisipatif, Remunerasi, dan Karakteristik Demografi terhadap Kinerja Manajerial dengan Berbagi Pengetahuan sebagai Variabel Mediasi. Disertasi Universitas Brawijaya Malang.

Kenis, I. 1979. Effects of Budgetary Goal Characteristics on Managerial Attitudes of Performance. The Accounting Review 54, pp. 707-722.

Kren. 1992. Budgetary Participation and Managerial Performance: The Impact of Information and Environmental Volatility. The Accounting Review, pp. 511-526.

Locke, E.A. 1968. Toward a Theory of Task Motivation and Incentives. Organizational Behavior and Human Performance, vol.3, pp.157-189.

Malina, M.A., dan Selto, F.H. 2004. Causality in a Performance Measurement Model. http: Ilwww.ssrn.com. Diakses 20 Agustus 2015.

Mallin, Chris, et al. 2015. The Remuneration of Independent Directors in the UK and Italy: An Empirical Analysis Based on Agency Theory. International Business Review 24, pp. 175-186.

Mardiasmo. 2009. Akuntansi Sektor Publik. Yogyakarta: ANDI.

Mensah, F.B dan Dogde, O.D. 2011. Performance-Based Pay as a Motivational Tool for Achieving Organisasional Performance: An Exploratory Case Study. International Journal of Business and Management, vol.6, no.12, pp. 270-285.

Mia, L dan Clarke. 1999. Market Competition, Use of Information Management Accounting System, Performance Unit Business. Management Accounting Research, pp. 137-158.

Mintje, N. 2013. Pengaruh TQM, Sistem Penghargaan dan Sistem Pengukuran Kinerja terhadap Kinerja Manajerial pada PT. Air Manado. Jurnal Riset Ekonomi, Manajemen, Bisnis dan Akuntansi Unsrat, vol.1, no.3.

Mulyadi, 2007. Sistem Akuntansi. Jakarta : Selemba Empat.

Muparrih, Pahlawansyah, Santoso, D. 2009. Analisis Pengaruh Budaya Organisasi dan Remunerasi terhadap Kinerja Pegawai melalui Kepuasan Kerja Pegawai Direktorat Jenderal Bea dan Cukai. Jurnal Riset Ekonomi dan Bisnis, vol.1, no.14, hal. 1-12.

Ng'ang'a, M.J., dan Nyongesa, W.J. 2012. The Impact of Organisational Culture on Performance of Educational Institutions. International Journal of Business and Social Science, vol. 3, no. 8.

Pollitt, C. 2006. Performance Management in Practice: a Comparative Study of Executive Agencies. Journal of Public Administration Research and Theory 16, pp. 25-44.

Pora, A. D. 2011. Remunerasi: Kompesasi dan Benefit. Jakarta : Rana Pustaka.

Rahman, S., Nasir, M., dan Handayani, S. 2007. Pengaruh Sistem Pengukuran Kinerja terhadap Kejelasan Peran, Pemberdayaan Psikologis dan Kinerja Manajerial (Pendekatan Partial Least Square) Penelitian terhadap Manajer Perusahaan Manufaktur di Jawa Tengah). Simposium Nasional Akuntansi 10. Makassar : Universitas Hasanudin.

Riyadi, S. 2011. Pengaruh Kompensasi Finansial, Gaya Kepemimpinan, dan Motivasi Kerja Terhadap Kinerja Karyawan pada Perusahaan Manufaktur di Jawa timur. Jurnal Manajemen dan Kewirausahaan, vol.13, no.1, pp. 40-45.

Robbins, S.P. 2003. Perilaku organisasi. Jakarta : PT. Indeks Kelompok Gramedia.

Rusman. 2015. Pengaruh Remunerasi, Budaya Organisasi, Karakgteristik Demografi, dan Pengawasan Fungsional terhadap Kinerja Pegawai Pengelola Keuangan (Studi pada Kementrian Agama Propinsi Sulawesi Tenggara). Tesis. Program Magister Akuntansi Universitas Brawijaya.

Sancoko, B. 2010. Pengaruh Remunerasi terhadap Kualitas Pelayanan Publik. Jurnal Ilmu Administrasi dan Organisasi 17, hal. 43-51 
Setiardja, G.A. 1990. Dialektika Hukum dan Moral dalam Pembangunan Indonesia. Yogyakarta: Kanisius.

Simmamora, V. 2014. Pengaruh Budaya Organisasi, Sistem Pengukuran Kinerja, dan Sistem Penghargaan terhadap Kinerja Manajerial pada PT. Federal Internatinal Finance di Kota Medan. Tesis. Program Studi Magister Akuntansi. Universitas Negeri Medan

Spekle, R.F. 2014. The Use of Performance Measurement Systems in The Public Sector: Effects on Performance. Management Accounting Research 25, pp. 131-146.

Supomo, B. 1998. Pengaruh Struktur dan Kultur Organisasional terhadap Keefektifan Anggaran Partisipatif dalam Peningkatan Kinerja Manajerial : Studi Empiris pada Perusahaan Manufaktur Indonesia. Tesis Program Pasca Sarjana Universitas Gadjah Mada (Tidak Dipublikasikan)

Tarigan, A.F. 2009. Analisis Faktor-Faktor yang Mempengaruhi Kinerja Pegawai dalam Organisasi Sektor Publik. Universitas Diponegoro

Trice, H.M dan J.M. Bayer. 1993. The Cultures of Work Organizations. Englewood Cliffs. NJ: Prentice Hall.

Tupamahu, K.H. 2009. Hubungan Sistem Pengukuran Kinerja Komprehensif dengan Kinerja Manajerial: Pemberdayaan Psikologis dan Kejelasan Peran Sebagai Variabel Moderating. Tesis. Program Magister Akuntansi Universitas Gadjahmada.

Otley, D. 1980. The Contigency Theory of Management Accounting: Achievement and Prognosis. Accounting Orgaizations and Society, vol. 5, pp. 413-428.

Verbeeten, F.H.M., 2008. Performance Management Practices in Public Sector Organizations: Impact on Performance. Accounting, Auditing and Accountability Journal 21, pp. 427-454.

Wibowo. 2011. Manajemen Kinerja. Jakarta: PT. RajaGrafindo Persada.

Widyastuti, Y. 2010. Pengaruh Persepsi Remunerasi Pegawai, Motivasi Kerja dan Disiplin Kerja terhadap Kinerja Pegawai di Kantor Pelayanan Perbendaharaan Negara (KPPN) Percontohan Serang Provinsi Banten. Tesis. Program Studi Ilmu Administrasi Negara. Universitas Sultan Ageng Tirtayasa.

Wilfred, O.N., Elijah, C,M., Muturi, W. 2014. Effect of Remuneration on Employees Performance in the Ministry of Internal Security: A Case of Kisii County. International Journal of Human Resource Studies, vol. 4, no.1 
The Effect of Performance Measurement System And Remuneration ... (Rokhimakhumullah) 